\title{
Ecologization of cultivar adopted technologies for scab protection and nutrition program of an apple tree in orchard and nursery
}

\author{
Andrei Kuzin ${ }^{1,2^{*}}$, Natalia Kashirskaya ${ }^{1}$, and Anna Kochkina ${ }^{1}$ \\ ${ }^{1}$ I.V. Michurin Federal Scientific Centre, Michurina str., 30, Michurinsk, 393774, Russia \\ ${ }^{2}$ Michurinsk State Agrarian University, Internatsionalnaya str., Michurinsk, 393760, Russia
}

\begin{abstract}
Different apple cultivars require a different approach to plant protection and nutrition according to their genotypic features. Currently, due to the relatively large number of cultivars in orchards and nurseries of horticultural farms, this approach is rarely used. Our work aimed to study the effectiveness of various foliar fertilizers and protection products in tank mixtures for the scab suppression and their impact on productivity according to cv's genotypic features of 'Lobo' and 'Zhigulevskoye'. The efficiency of protection and nutrition programs was studied in the nursery and orchard circumstances. According to generally accepted methods, we did our research in 2013-2015 in the experimental orchard and nursery of I.V. Michurin Federal Scientific Centre. We determined the biological effectiveness of the plant protection systems used, the development of productivity components (fruitset from free pollination, average fruit weight and yield per tree), the content of primary nutrients in soil, leaves, and fruits. The ecologized system has provided a sufficiently high level of protection, which allows recommending to producers. The introduction of such ecologized protection and nutrition systems that reduce the pesticide load assumes a much higher account of the interaction of apple trees with other plant and animal species and lifeless components of the nursery and orchard ecosystem. The use of an ecologized foliar nutrition system provided a high enough level of plant protection effectiveness, especially when combined with regular soil fertilizer application, and optimizing the mineral composition of leaves and fruits. Biologization of soil nutrition is one of the most critical tasks for preserving soil fertility in intensive horticulture. The soil application of bacterial fertilizers stimulated a significant increase in the average annual growth rate and stem diameters of young apple trees in the nursery and yield in the orchard. However, the highest results were obtained when applying bacteria cultures and artificial fertilizers at a reduced application rate.
\end{abstract}

A relatively large amount of new high-density orchards is planted in Russia every year. This task requires high-quality young apple trees for planting. So, nurseries also have to increase the production of young trees. Intensive horticulture is supposed to increase nutrient supply

\footnotetext{
*Corresponding author: andrey.kuzin1967@yandex.ru
} 
and strengthen plant protection to obtain a high output of young trees in nurseries and large yields with high-quality fruits in orchards. The result is the increase of anthropogenic pressure on the environment because of the broad use of pesticides and artificial (mineral) fertilizers. The protection and nutrition of plants must be based on environmentally friendly products according to the particular demand of different cultivars to reduce the environment's pollution. One of the problems of modern horticulture in Central Russia is a large number of apple cultivars. Different apple cultivars have various resistances to pests and diseases as well as nutrition requirements.

It is necessary to understand pathogen specifics for the continuous development of new methods for scab control. The pathogen causes strong growth of the disease development on cultivated apple trees and affects wild apple species [1]. The tremendous amount of knowledge of fungi biology was obtained while studying Venturia inaequalis. It made a significant contribution to the development of scab control methods [2]. The infection of apple leaves and fruits by Venturia inaequalis spores has some stages: on the surface - the adhesion, germination, appressoria formation, then the penetration into a host plant and inside the plant organism - colonization and spore formation [3].

The apple tree developed mechanisms to prevent scab disease. Plants contain substances that inhibit the development of pathogens; for instance, different polyphenols. Various researchers noted that the content of polyphenols is increased in infected plant tissues [4,5]. The plant immune system's cell receptors recognize pathogen elicitors formed from damaged plant cells [6]. To protect nurseries and orchards from scab, producers use the range of resistance inductors. Some of these products have both a direct effect on the pathogen and through altered metabolism. The immune action of many products against scab has the next mechanism: after penetration into the plants, they are involved in metabolic processes and change them enhancing the protective response as it inherent for resistant cultivars [7]. So, there are two groups of protection products: the first is the preparations that changed plant metabolism to be unfavorable for the parasite. The second one compounds with a doubleaction (suppressing pathogen and altering plant metabolism to be adverse against apple scab. Combining plant protection products and foliar fertilizers in tank mixtures makes it possible to integrate several operations in one, which helps to reduce costs. The use of macro- and micronutrients, in this case, increases plants' resistance to fungal diseases [8]. Such a combined application of protection products and fertilizers is often more effective than separate treatments with these products [9]. Foliar nutrition is essential to supply plants with micronutrients during the period with the highest demand regardless of their soil availability [10]. However, it is necessary to provide apple trees in orchards with macronutrients for the maximum realization of plants' biological potential, which is possible in suitable amounts by soil application only [11].

Soil application of bacterial fertilizers can significantly increase the apple tree rhizosphere's microbiological activity. It improves the plant supply with available nitrogen [12]. The use of biological fertilizers made a positive impact on soil microbial activity and the amount of available potassium in the soil root layer [13].

The harmfulness of various diseases, including scab, has been increasing. Plant protection products' effectiveness has been declining in recent years, and weather stress contributes to the scab's severity: heavy rainfall during the growing season, long periods of low temperatures, etc. [14].

Nevertheless, reducing environmental pollution with pesticides and mineral fertilizers in agriculture is quite acute. The introduction of biologized technologies (according to apple cultivar genotypic specificity) is an essential task for the coming years.

The research was carried out in 2011-2015 in the experimental nursery and orchard of the I.V. Michurin Federal Scientific Centre. One-year-old apple trees of cv's 'Zhigulevskoye' and 'Lobo' were grafted on rootstock B396, and the orchard was planted in 2007. In the nursery, 
trees were grown at $90 \times 20 \mathrm{~cm}$, and in the orchard $4.5 \times 1 \mathrm{~m}$ (2222 trees ha-1). The experiment was arranged at a randomized block design with three replicates of 20 young apple trees and 5 mature plants each. Scab development degree was determined by the area of lesions on the surface of leaves and fruits on a point scale (leaves: 0 - no scab symptom; 1 - sporadic small spots, up to $1 \%$ of leaf surface; 2 - small or average size lesions, $1-10 \%$ of leaf surface; 3 - large or many small spots, $11-25 \%$ of leaf surface; 4 - large lesions with a dark coating of fungal sporulation, $25-50 \%$ of leaf surface; 5 - large spots with fungal sporulation, more than $50 \%$ of the leaf surface. Abbott's formula was used to calculate the biological efficiency of protection treatments (Formula 1):

$$
C=\frac{X-Y}{X} \times 100
$$

where $\mathrm{C}$ is the biological efficiency (percent control)

$X$ is the prevalence of scab in the untreated control

$Y$ is the prevalence of scab in the treated plot.

The average annual growth rate and increase of stem diameters were measured in the nursery. We visually calculated the number of flowers, small fruits (after fruit drop), and fruits on trees before harvest in the orchard. The weighting of 100 fruits determined the average fruit mass. The yield was recorded after harvesting for experimental plots and then converted in tones per hectare. Soil and leaf samples for analyzes were taken in the middle of August, fruits - after harvest. The nitrogen content was determined by the Kjeldahl method on AKV-20 (Russia), phosphorus - by SnCl2 coloring, and detecting at $750 \mathrm{~nm}$ on photometer KFK-3.01 (Russia), potassium, and calcium on flame photometer FPA 2-01 (Russia). The data obtained in the experiment were analyzed statistically by Fisher's method. We calculated the Lowest Significant Difference (LSD) between various treatments $(\mathrm{P}<0.05)$. The differences were higher than the computed LSD value were considered significant.

Experiment design:

1. Control without treatments

2. Ecologized protection system adopted to cultivars:

Zhigulevskoye (ZP) - Delan $\left(0,6 \mathrm{~kg} \mathrm{ha}^{-1} \times 2\right)$, Stroby $\left(0,2 \mathrm{~kg} \mathrm{ha}^{-1} \times 2\right)$, Bactofit $(8,0 \mathrm{~kg}$ $\mathrm{ha}^{-1}$ X 3), Rhizoplan $\left(51 \mathrm{ha}^{-1}\right)$;

Lobo (LP) - Merpan (2,5 kg ha' $\mathrm{kg}^{-1}$, Medea (1,0 $\left.1 \mathrm{ha}^{-1}\right)$, Rhizoplan (5 $\left.1 \mathrm{ha}^{-1}\right)$, Score (0,25 1 $\left.\mathrm{ha}^{-1}\right)$, Bactofit $\left(8, \mathrm{~kg} \mathrm{ha}^{-1} \mathrm{x} 1\right)$;

3. Ecologized foliar nutrition system adopted to cultivars + ecologized foliar nutrition system adopted to cultivars:

Zhigulevskoye (ZFN) - Alga 600, Seamino + Proboron + RootMost; Alga 600 + AmiCa; (RootMost + AmiCa) x 2;

Lobo (LFN) - Alga 600, Seamino + Proboron + RootMost; Proboron; Proboron + AmiCa, Seamino + AmiCa, Alga $600+$ AmiCa; (RootMost + AmiCa) x 4;

4. Ecologized protection system adopted to cultivars + ecologized foliar nutrition system adopted to cultivars + Azotovit and Fosfatovit (BF) soil application in amounts recommended by producer;

5. Ecologized protection system adopted to cultivars + ecologized foliar nutrition system adopted to cultivars + Azotovit and Fosfatovit + artificial fertilizers (AF) soil application $\left(\mathrm{N}_{30} \mathrm{P}_{30} \mathrm{~K}_{50}\right.$ active substances per ha).

We didn't apply bacterial protection products in the nursery, but we reduced the number of sprayings. We didn't apply "very toxic" and "toxic" products but used "slightly toxic" and "practically nontoxic" preparations.

Zhigulevskoye protection system (ZPN): Polyram $\left(2,0 \mathrm{~kg} \mathrm{ha}^{-1} \mathrm{x} 2\right)$, Tercel $\left(2,0 \mathrm{~kg} \mathrm{ha}^{-1} \mathrm{x}\right.$ 1), Zato $\left(0,14 \mathrm{~kg} \mathrm{ha}^{-1} \times 2\right)$. 
Lobo protection system (LPN): Cuproxat $\left(5.01 \mathrm{ha}^{-1} \mathrm{x}\right.$ 1) Score $\left(0.21 \mathrm{ha}^{-1} \mathrm{x}\right.$ 1), Delan (0.6 $\mathrm{kg} \mathrm{ha}^{-1}$ x 2).

Spring treatments with the agrochemical Proboron were excluded from the cultivar adopted systems of foliar nutrition. Spaying with the AmiCa was done only one time during the growing season in early June.

Weather conditions over the years of research have been favorable for the development of scab. Growing seasons were characterized by frequent precipitation and average daily temperature, contributing to the fungus' active life. The scab development on 'Zhigulevskoye' young tree leaves in the Control was $8.1 \%$, on 'Lobo' - 6.5\% (Table 1). The combined use of protection products with foliar fertilizers and soil application of biological fertilizers provided well scab suppression and increased biological efficiency.

Table 1. Development and biological efficiency against leaf scab in nursery

\begin{tabular}{|l|c|c|c|}
\hline \multirow{2}{*}{ Treatment } & \multicolumn{2}{c|}{ Leaves } & \multirow{2}{*}{ Biological efficiency, \% } \\
\cline { 2 - 4 } & Prevalence, \% & Development, \% & \\
\hline \multicolumn{4}{|c|}{ 'Zhigulevskoye' } \\
\hline Control & 19.5 & 8.1 & - \\
\hline ZPN & 8.0 & 0.9 & 88.9 \\
\hline ZPN+ZFN & 7.2 & 0.7 & 91.4 \\
\hline ZPN+ZFN+BF & 6.8 & 0.6 & 94.5 \\
\hline ZPN+ZFN+BF+AF & 6.1 & 0.4 & - \\
\hline \multicolumn{3}{|c|}{ 'Lobo' } \\
\hline Control & 14,7 & 6,5 & 90,7 \\
\hline LPN & 5,0 & 0,6 & 92,3 \\
\hline LPN+LFN & 4,1 & 0,5 & 93,8 \\
\hline LPN+LFN+BF & 3,4 & 0,4 & 96,0 \\
\hline LPN+LFN+BF+AF & 3,0 & 0,2 & \\
\hline
\end{tabular}

The scab development on 'Lobo' young tree leaves was lower compared to 'Zhigulevskoye'. So, scab expansion on 'Zhigulevskoye' was $0.4 \%$ and on 'Lobo' $-0.2 \%$.

The development of scab in the 'Zhigulevskoye' control treatment (mature trees) was $25.4 \%$ on the leaves and the fruits $-13.0 \%$; on the cv. 'Lobo' $-21.6 \%$ and $9.8 \%$, respectively (Table 2).The combined use of an ecologized protection system with foliar fertilizing based on sea-weed extracts and soil application of biological fertilizers contributed to reducing scab development and increasing biological efficiency.

Table 2. Effectiveness against scab on mature apple trees

\begin{tabular}{|l|c|c|c|c|c|c|c|}
\hline \multirow{2}{*}{ Treatment } & Prevalence, \% & \multicolumn{2}{c|}{ Development, \% } & Biological efficiency, \% \\
\cline { 2 - 7 } & leaves & fruits & leaves & fruits & leaves & fruits \\
\hline 'Zhigulevskoye' & - \\
\hline Control & 56.0 & 26.8 & 25.4 & 13.0 & - & 86.9 \\
\hline ZP & 21.6 & 13.6 & 2.8 & 1.7 & 88.9 & 88.5 \\
\hline ZP+ZFN & 20.2 & 12.8 & 2.5 & 1.5 & 90.1 & 90.0 \\
\hline ZP+ZFN+BF & 17.4 & 10.1 & 2.2 & 1.3 & 91.3 & 93.1 \\
\hline ZP+ZFN+BF+AF & 15.4 & 7.8 & 1.8 & 0.9 & 92.9 & - \\
\hline \multicolumn{7}{|c|}{ 'Lobo' } \\
\hline Control & 45.5 & 22.9 & 21.6 & 9.8 & - & - \\
\hline LP & 20.5 & 8.9 & 2.1 & 1.1 & 90.2 & 88.8 \\
\hline LP+LFN & 14.3 & 7.3 & 1.3 & 1.0 & 93.8 & 89.8 \\
\hline LP+LFN+BF & 13.8 & 6.9 & 1.0 & 0.8 & 95.4 & 91.8 \\
\hline LP+LFN+BF+AF & 11.6 & 5.1 & 0.7 & 0.5 & 96.7 & 94.9 \\
\hline
\end{tabular}

The content of hydrolyzable soil nitrogen in experimental plots without soil fertilizer application was relatively low (Table 3 ). The amount of available phosphorus in the soil 
without fertilizing was practically the same. The content of exchangeable potassium in the soil was at the optimum level. Soil calcium status was high, but the availability of this nutrient for plants and its distribution among the organs depends on many factors. For instance, this nutrient availability for plants decreases with high soil potassium levels [15]. Simultaneously, increasing the potassium supply during fruit growth and ripening stimulates a significant increase in productivity [16]. In this period, the demand for calcium increases because it is essential for good fruit storability [17].

Table 3. Content of available essential nutrients in the soil of experimental plots $(0-40 \mathrm{~cm})$

\begin{tabular}{|l|c|c|c|c|}
\hline \multicolumn{1}{|c|}{ Treatment } & $\begin{array}{c}\text { Hydrolyzable N, } \\
\mathrm{mg} \mathrm{kg}^{-1} \text { soil }\end{array}$ & $\begin{array}{c}\mathrm{P}_{2} \mathrm{O}_{5}, \\
\mathrm{mg} \mathrm{kg}^{-1} \text { soil }\end{array}$ & $\begin{array}{c}\mathrm{K}_{2} \mathrm{O}, \\
\mathrm{mg} \mathrm{kg}^{-1} \text { soil }\end{array}$ & $\begin{array}{c}\mathrm{CaO} \\
\mathrm{Mmol} / 100 \\
\mathrm{~g}^{-1} \text { soil }\end{array}$ \\
\hline 'Zhigulevskoye' \\
\hline Control & 114.5 & 122.8 & 133.1 & 19.2 \\
\hline ZP & 110.7 & 129.5 & 136.4 & 18.6 \\
\hline ZP+ZFN & 107.4 & 131.9 & 135.8 & 19.7 \\
\hline ZP+ZFN+BF+AF & 99.2 & 126.6 & 140.8 & 18.7 \\
\hline \multicolumn{5}{|c|}{ 'Lobo' } \\
\hline Control & 156.1 & 144.5 & 142.7 & 19.5 \\
\hline LP & 117.8 & 117.9 & 136.2 & 17.3 \\
\hline LP+LFN & 118.7 & 98.8 & 144.4 & 16.9 \\
\hline LP+LFN+BF & 113.8 & 144.7 & 135.9 & 17.6 \\
\hline LP+LFN+BF+AF & 148.6 & 133.8 & 117.7 & 16.3 \\
\hline $\begin{array}{l}\text { Optimum levels of soil nutrients } \\
\text { for chernozems in Central Russia }\end{array}$ & 157.4 & 163.4 & 155.8 & 16.1 \\
\hline
\end{tabular}

The application of ZFN and LFN optimized leaf and fruit nitrogen status of both cultivars. But the best level of this nutrient we observed in the treatment with soil application of BF and AF (Table 4).

Table 4. The content of primary nutrients in leaves of one-year-old and mature apple trees,

$\%$ d.m.

\begin{tabular}{|c|c|c|c|c|c|c|c|}
\hline \multirow{2}{*}{ Treatments } & \multicolumn{3}{|c|}{ One-year old trees } & \multicolumn{4}{|c|}{ Mature tree } \\
\hline & $\mathrm{N}$ & $\mathrm{P}$ & $\mathrm{K}$ & $\mathrm{N}$ & $\begin{array}{l}\mathrm{P} \\
\end{array}$ & $\mathrm{K}$ & $\mathrm{Ca}$ \\
\hline \multicolumn{8}{|c|}{ 'Zhigulevskoye' } \\
\hline Control & 1.91 & 0.59 & 1.64 & 1.53 & 0.35 & 1.12 & 1.42 \\
\hline $\mathrm{ZP}$ & 1.85 & 0.46 & 1.68 & 1.54 & 0.39 & 1.21 & 1.43 \\
\hline $\mathrm{ZP}+\mathrm{ZFN}$ & 1.87 & 0.39 & 1.67 & 1.85 & 0.41 & 1.44 & 1.78 \\
\hline $\mathrm{ZP}+\mathrm{ZFN}+\mathrm{BF}$ & 2.05 & 0.55 & 1.62 & 1.89 & 0.41 & 1.31 & 1.72 \\
\hline $\mathrm{ZP}+\mathrm{ZFN}+\mathrm{BF}+\mathrm{AF}$ & 2.36 & 0.61 & 2.02 & 2.12 & 0.47 & 1.55 & 1.81 \\
\hline $\begin{array}{l}\text { LSD }_{05} \\
\end{array}$ & 0.22 & 0.07 & 0.17 & 0.21 & 0.05 & 0.11 & 0.10 \\
\hline \multicolumn{8}{|c|}{ 'Lobo' } \\
\hline Control & 1.77 & 0.56 & 1.71 & 1.62 & 0.30 & 0.96 & 1.55 \\
\hline LP & 1.67 & 0.58 & 1.85 & 1.58 & 0.32 & 1.01 & 1.54 \\
\hline LP+LFN & 1.83 & 0.61 & 1.82 & 1.76 & 0.32 & 1.11 & 1.88 \\
\hline $\mathrm{LP}+\mathrm{LFN}+\mathrm{BF}$ & 1.86 & 0.69 & 2.02 & 1.88 & 0.34 & 1.08 & 1.85 \\
\hline $\mathrm{LP}+\mathrm{LFN}+\mathrm{BF}+\mathrm{AF}$ & 2.03 & 0.72 & 2.54 & 2.04 & 0.33 & 1.27 & 1.79 \\
\hline LSD $_{05}$ & 0.19 & 0.06 & 0.20 & 0.23 & 0.04 & 0.12 & 0.15 \\
\hline Optimal level & $2.0-2.6$ & $0.5-0.7$ & $1.8-2.1$ & $1.8-2.5$ & $0.3-0.5$ & $1.3-1.5$ & $1.4-2.0$ \\
\hline
\end{tabular}

We didn't see the significant difference in the nitrogen content in the leaves of mature trees of both cultivars in corresponded treatments. The application of BF and AF, together with foliar fertilizer sprayings, provided the optimum nitrogen level in both cultivars' leaves 
in the nursery. The phosphorus leaf status had no significant differences in all treatments with mature trees. It was on an optimal level. Content of phosphorus in one-year old-trees was more than in leaves of mature trees. 'Lobo' young trees had optimal phosphorus status in all variants. But in 'Zhigulevskoye trees in the treatments $\mathrm{ZP}$ and $\mathrm{ZP}+\mathrm{ZFN}$, this nutrient concentration was lower (like in mature tree leaves). The phosphorus fruit status was also functional except for the variant with tank mixture ZP+ZFN application, in all treatments on cv. 'Lobo'.

The potassium content in apple leaves (despite the relatively high availability of soil) was determined mainly by fertilizers on the leaf and soil. The content of potassium in the leaves of young trees was higher than in mature trees. We saw a little excess of potassium in the leaves of 'Lobo' one-year-old trees when mineral fertilizers, including potassium sulfate, were applied. In the other treatments on 'Lobo', the potassium leaf status was on an optimal level. The potassium concentration in the leaves of 'Zhigulevskoye' young trees increased up to optimal level by soil application of the same rate of potash fertilizer, but in other treatments, this nutrient level was lower than the optimal limit.

The highest potassium content in the leaves of mature trees was observed when adding potassium sulfate to the soil but only in the 'Zhigulevskoye'. Also, plants of this cultivar responded better to the use of foliar fertilizing. In the 'Lobo', only the sol application of mineral fertilizers provided potassium's optimum in leaves. However, the potassium content in the fruit corresponded to the optimal level in all the experiment variants on the $\mathrm{cv}$. 'Zhigulevskoye'. It was most likely due to potassium's outflow from the leaves to the fruit during their maturation. Potassium is a very mobile nutrient in plants, and its content in the fruit is comparable to the leaves' concentration. So, there is a different response of apple cultivars to foliage and soil fertilization. It confirms the need for a differentiated approach to the development of the soil fertilization program.

The high content of calcium in fruits is crucial for improving the keeping capacity within cultivar genotypic specificity [18]. The use of ZFN significantly increased the calcium content in the fruits of the cv. 'Zhigulevskoye' (Table 5). The use of LFN on the cv. 'Lobo' stimulated an increase in the calcium content in the fruits only without potassium sulfate soil application, despite an increase in the number of treatments with calcium-containing agrochemicals of plants, and the concentration of calcium in the fruits was generally lower than in the 'Zhigulevskoye'. The decrease of calcium fruit status was in both cultivars when adding potassium to the soil. I.e., the increase in the potassium level in the soil reduced the availability of soil calcium, which emphasizes the importance of foliar calcium fertilizing and augmentation of their multiplicity to optimize its content in the fruit when a potassium application rate is boosting.

Table 5. The content of primary nutrients in fruits, $\%$ d.m.

\begin{tabular}{|l|c|c|c|c|c|c|c|c|}
\hline \multirow{2}{*}{$\begin{array}{c}\text { Treatments } \\
\text { (according to cultivars) }\end{array}$} & \multicolumn{4}{|c|}{ 'Zhigulevskoye' } & \multicolumn{4}{c|}{ 'Lobo' } \\
\cline { 2 - 10 } & $\mathrm{N}$ & $\mathrm{P}$ & $\mathrm{K}$ & $\mathrm{Ca}$ & $\mathrm{N}$ & $\mathrm{P}$ & $\mathrm{K}$ & $\mathrm{Ca}$ \\
\hline Control & 0.26 & 0.068 & 0.75 & 0.031 & 0.20 & 0.048 & 0.57 & 0.020 \\
\hline $\mathrm{P}$ (Z and L) & 0.27 & 0.062 & 0.72 & 0.034 & 0.23 & 0.035 & 0.55 & 0.021 \\
\hline $\mathrm{P}+\mathrm{FN}(\mathrm{Z}$ and L) & 0.33 & 0.055 & 0.74 & 0.049 & 0.26 & 0.059 & 0.63 & 0.041 \\
\hline $\mathrm{P}+\mathrm{FN}$ (Z and L) + BF & 0.29 & 0.062 & 0.64 & 0.043 & 0.31 & 0.032 & 0.61 & 0.038 \\
\hline $\mathrm{P}+\mathrm{FN}$ (Z and L) + BF + AF & 0.37 & 0.069 & 0.77 & 0.029 & 0.39 & 0.058 & 0.74 & 0.024 \\
\hline \multicolumn{1}{|c|}{ HCP 05} & 0.04 & 0.009 & 0.09 & 0.005 & 0.03 & 0.007 & 0.08 & $0.0-4$ \\
\hline Optimum level & $0.3-0.4$ & $0.07-0.10$ & $0.6-0.8$ & $0.04-0.06$ & $0.3-0.4$ & $0.07-0.10$ & $0.6-0.8$ & $0.04-0.06$ \\
\hline
\end{tabular}

The highest fruit set from free pollination was in both cultivars in the variant with soil application, including artificial fertilizers (Table 5). The application of ecologized foliar fertilizing also stimulated a significant increase of fruitset compared to the Control. 
A maximum increase of the nursery's average annual growth rate was by soil application (Table 5). An interesting fact is that the soil application of potassium sulfate in the complex of artificial fertilizers did not have a noticeable effect on this indicator on 'Lobo' young trees. Then, the maximum elongation of plants was fixed in this treatment on 'Zhigulevskoye' oneyear-old trees. The soil application of bacterial and artificial fertilizers stimulated the significant increase of stem diameters by both cultivars.

Table 6. Development of productivity and quality components

\begin{tabular}{|c|c|c|c|c|c|}
\hline \multirow[b]{2}{*}{ Treatment } & \multicolumn{2}{|c|}{ One-year old trees } & \multicolumn{3}{|c|}{ Mature trees } \\
\hline & $\begin{array}{c}\text { Average } \\
\text { annual } \\
\text { growth rate, } \\
\mathrm{cm}\end{array}$ & $\begin{array}{c}\text { Annual } \\
\text { increase of } \\
\text { stem } \\
\text { diameter, } \\
\text { mm } \\
\end{array}$ & $\begin{array}{c}\text { Fruitset from } \\
\text { free } \\
\text { pollination, } \\
\%\end{array}$ & $\begin{array}{c}\text { Average } \\
\text { fruit mass, } \\
\mathrm{g}\end{array}$ & $\begin{array}{l}\text { Yield, } \\
\text { T ha }^{-1}\end{array}$ \\
\hline \multicolumn{6}{|c|}{ 'Zhigulevskoye' } \\
\hline Control & 55 & 3.8 & 9.2 & 176.1 & 21.7 \\
\hline $\mathrm{ZP}$ & 49 & 3.4 & 7.2 & 179.9 & 19.4 \\
\hline $\mathrm{ZP}+\mathrm{ZFN}$ & 59 & 3.2 & 10.8 & 175.3 & 21.5 \\
\hline $\mathrm{ZP}+\mathrm{ZFN}+\mathrm{BF}$ & 66 & 4.8 & 11.1 & 181.9 & 23.4 \\
\hline $\mathrm{ZP}+\mathrm{ZFN}+\mathrm{BF}+\mathrm{AF}$ & 72 & 5.0 & 12.7 & 189.0 & 24.9 \\
\hline $\mathrm{LSD}_{05}$ & 5 & 0.7 & 0.8 & 10.3 & 1.4 \\
\hline \multicolumn{6}{|c|}{ 'Lobo' } \\
\hline Control & 58 & 2.7 & 10.8 & 157.3 & 18.2 \\
\hline LP & 61 & 3.3 & 10.2 & 149.2 & 19.3 \\
\hline $\mathrm{LP}+\mathrm{LFN}$ & 64 & 3.4 & 14.1 & 146.4 & 20.2 \\
\hline $\mathrm{LP}+\mathrm{LFN}+\mathrm{BF}$ & 78 & 3.9 & 14.7 & 166.4 & 23.1 \\
\hline $\mathrm{LP}+\mathrm{LFN}+\mathrm{BF}+\mathrm{AF}$ & 71 & 4.5 & 15.6 & 163.2 & 23.8 \\
\hline $\begin{array}{r}\mathrm{HCP}_{05} \\
\end{array}$ & 8 & 0.6 & 1.1 & 11.2 & 2.1 \\
\hline
\end{tabular}

Improving soil nutritional status by applying only microbial fertilizers, bacterial, and mineral fertilizers increased the efficiency of using an ecologized foliar nutrition system. The application of fertilizers to the soil contributed to a significant increase in the average fruit weight of both studied cultivars, especially when combined with bacterial and mineral fertilizers. The use of an ecologized foliar nutrition system did not provide a significant increase in yield than in control, although we noted different responsiveness of cultivars to foliar fertilizing. Combined application of plant protection products and fertilizers made a positive effect on the increase of annual growth rate and stem diameters of one-year-old apple trees of both cultivars. The most impact was by applying fertilizer complex, including potassium sulfate, despite the relatively high concentration in the soil.

Thus, using an ecologized system of protection against scab in the tank mixture with foliar fertilizing combined with $\mathrm{BF}$ and $\mathrm{AF}$ soil application allowed reducing the development of scab and increasing the biological effectiveness of protection. We observed a similar effect both in the nursery and in the orchard. The use of an ecologized system of foliar fertilizing optimized the nitrogen content in leaves and calcium in apple fruits of both studied varieties. Trees of cv. 'Zhigulevskoye' responded better than 'Lobo' to leaf nutrition, but in 'Lobo' plantings, soil fertilizer use had the best responsiveness. Soil application of potash sulfate provided an increase in yield, but the need for leaf calcium rose against this background. The potassium application rate in our study in the orchard more corresponded to cv. 'Zhigulevskoye' requirements for 'Lobo' trees it should be increased. The use of bacterial fertilizers allows you to minimize artificial fertilizers' rates to ensure the optimal soil nutrients' optimal level but does not entirely replace them. The most considerable average annual growth rate was by the combined application of bacterial and artificial fertilizers. The maximum yield was observed in the variant with the joint introduction of bacterial and 
mineral fertilizers into the soil, mainly due to an increase in the fruit's average weight. The studied fertilizer application rates within these conditions were more satisfied for 'Lobo' oneyear-old trees; by growing 'Zhigulevskoye' young trees, this soil application rate should be increased by $10 \%$.

\section{References}

1. G. Jha, K. Thakur, P. Thakur, J. Biomed. Biotechnol. 2009(10), 680160, (2010), https://doi.org/10.1155/2009/680160.

2. J.K. Bowen, C.H. Mesarich, V.G. Bus, R.M. Beresford, K.M. Plummer, M.D. Templeton, Mol. Plant Pathol. 12(2), 105 -122, (2011), https://doi.org/10.1111/j.13643703.2010.00656.X.

3. K. Ikeda, K. Inoue, H. Kitagawa, H. Meguro, S. Shimoi, P. Park, in Plant Pathology, Intechopen, (2012), 131 - 150, https://doi.org/10.5772/30801.

4. M. Golebiowski, E. Maliński, M. Szankin, M. Marszeniuk, M. Paszkiewicz, P. Stepnow ski, Chem. Papers. 64(6), 729-733, (2010), https://doi.org/10.2478/s11696-010-0067-x.

5. M.M. Petkovsek, A. Slatnar, F. Stampar, R. Veberic, Biol. Plantarum. 55(4), 725, (2011), https://doi.org/10.1007/s10535-011-0176-6A.

6. N.A.A. Malik, I.S. Kumar, K. Nadarajah, Int. J. Mol. Sc. 21, 963, (2020), https://doi.org/10.3390/ijms21030963.

7. E.J. Andersen, S. Ali, E. Byamukama, Y. Yen, M.P. Nepal. Genes (Basel). 9(7), 339 (2018), https://doi.org/10.3390/genes9070339.

8. N. Gupta, S. Debnath, S. Sharma, P. Sharma, J. Pirohit. In Agriculturally Important Microbes for Sustainable Agriculture. Springer, Singapore, 217-262, (2017), https://doi.org/10.1007/978-981-10-5343-6 8.

9. A.I. Kuzin, N.Y. Kashirskaya, A.M. Kochkina, B.I. Smagin. International Journal of Engineering and Advanced Technology. 8(6), 3613-3620, (2019), https://doi.org/10.35940/ijeat.F8843.088619.

10. G. Kurešova, L. Menšik, J. Haberle, P. Svoboda. Plant, Soil and Environment. 65(6), 320327, (2019), https://doi.org/10.17221/196/2019-PSE.

11. T. Milošević, N. Milošević. J. Soil Sci. Plant Nutr. 15(1), 76-83, (2015), https://doi.org/ 10.4067/S0718-95162015005000007.

12. A.I. Kuzin, Yu.V. Trunov, A.V. Solovyev. Sel'skokhozyaistvennaya Biologia. 53(5), 1013-1024, (2018), https://doi.org/10.15389/agrobiology.2018.5.1013rus.

13. W. Ali, M. Nadeem, W. Ashiq, M. Zaeem, S.S.M. Gilani, S. Rajabi-Kamseh, T.H. Pham, V. Kvanagh, R. Thomas, M. Gheema. Sci. Rep. 9. 17297, (2019), https://doi.org/10.103 8/s41598-019-53906-8.

14. E. Gonzáles-Domíngues, J. Armengol, V. Rissi, PLoS ONE. 9(9), 107547, (2014), https://doi.org/10.1371/journal.pone.0107547.

15. M.A. Danner, S. Scariotto, I. Citadin, G.A. Penso, L.S. Cassol. Pesq. Agropec. Trop.. 45(3), 265-273, (2015), https://doi.org/10.1590/1983-40632015v4534457.

16. S. Yoursuf, M.A. Sheikh, S. Chand, A. Anjum, Journal of Applied and Natural Sciences. 10(4), 1332-1340, (2019), https://doi.org/10.31018/jans.v10i4.1945.

17. W.S. Conway, C.E. Sams, K.D. Hickey. Acta Hort., 594, 413-419, (2002), https://doi.org/10.17660/ActaHortic.2002.594.53.

18. B.Hocking, S.D. Tyerman, R.A. Burton, M. Gilliham. Front. Plant Sci. 7, 569, (2016), https://doi.org/10.3389/fpls.2016.00569. 